\title{
13 \\ Plutarch and Dio on Cicero at the Trial of Milo
}

\author{
Lynn Fotheringham
}

Plutarch Cicero 35 and Dio Roman History 40.48-55 are two of the sources that make Milo's trial de vi after the death of Clodius one of the best-attested of Ciceronian trials. Ciceronian scholars (including myself), interested in these passages for the evidence they provide for that trial and its context, ${ }^{1}$ have tended to examine them in isolation from the works of which they form a part. This is unfortunate, since contextualizing the account of the trial within those works sheds light on the writers' reasons for including this event in their narratives, on their choices about how to present it, and therefore on the value and nature of the evidence they provide. My focus remains on Cicero and his ancient reception, but the current volume provides me with a welcome opportunity to try to do more justice to Plutarch and Dio themselves.

Besides including the episode, Plutarch and Dio share an explanation for Cicero's below-par performance at the trial, presenting a vivid picture of his failure to deliver his defence speech due to his fear of the soldiers posted by Pompeius in the forum. In other respects the accounts of the two authors are different. Dio's version is more carefully contextualized: so, he establishes the political context of electoral chaos at Rome (40.45.1-46.3) and includes rumours of a dictatorship for Pompeius (40.45.5-46.1); narrates the skirmish that led to Clodius' death (40.48.2) and outlines the consequent

1 Discussions of the trial include Settle 1963, Lintott 1974, Ruebel 1979, Marshall 1985, Dyck 2002, Steel 2005: 118-30, and Fotheringham 2006. 
urban violence (40.49.2) that prompted Pompeius' sole consulship (40.50.4-5); recounts Pompeius' legislation (40.52.1-3, 55.2) and subsequent judicial activity, including the condemnation of some Clodiani (40.52.1, 53.1, 55.1-4). Plutarch omits almost all this, merely stating that 'after these events Milo killed Clodius' and giving a minimalist explanation of Pompeius' role (35.1-2). It is no surprise that the annalistic historian provides more background than the biographer, but there is more at stake here: Plutarch is not so neglectful of the political background everywhere in the Cicero, and Dio does not devote as much space to every year as he does to $52 \mathrm{BC}^{2}$ The reasons for particular omissions and inclusions will be worth considering.

Other sources for these events, useful for comparative purposes, include Cicero's published Pro Milone and some of his letters, ${ }^{3}$ some comments by Quintilian, ${ }^{4}$ and one remark in the non-Asconian scholia. ${ }^{5}$ More comparable to Plutarch and Dio are the narrative accounts of Asconius and Appian. As befits a work whose entire focus is on a speech supposedly delivered at Milo's trial, Asconius' commentary on the Pro Milone provides the most detailed account of that trial and its context. ${ }^{6}$ It has no broader narrative context, but its immense amount of detail makes it too complex to analyse here except for comparative purposes. One significant difference with Plutarch and Dio is that Asconius blames the heckling of Clodiani for Cicero's below-par performance, rather than fear of Pompeius' soldiers (41C). Appian ( $B C$ 2.20-24) is interesting for our current purposes because he manages to narrate the momentous events of 52 BC without paying much attention to Milo's trial or mentioning Cicero's role. 7 The historian of civil conflict, in contrast to Plutarch, focuses not on the trial but on its violent context; his account of this event is therefore of less value for understanding Cicero's reception.

Each of the four narrative sources provides information that the others omit, although Asconius gives more unique information than can be listed here. For example, Plutarch says that Milo himself

${ }^{2}$ Roman History 40.45-66 is devoted to events at Rome in 53-50 BC; of these twenty-two chapters, twelve (40.47-58) are devoted to $52 \mathrm{BC}$.

3 Q. fr. 3.4, 3.6; Fam. 2.6, 3.10; Att. 9.7b.

4 References to the trial: 2.20.8, 3.6.93, 4.1.20, 31, 4.3.17, 6.3.49. Quintilian admired the Pro Milone and cites it frequently.

5 Schol. Bob. 173 Stangl. $\quad{ }^{6}$ On Asconius, see Marshall 1987 and Lewis 2006.

7 Cicero appears only at Appian BC 2.20, where Milo is identified as having played a role in Cicero's recall from exile (cf. $B C$ 2.16). 
refused to wear mourning (which is compatible with Cic. Pro Milone 92-105, but not explicitly stated there), but had Cicero brought to the forum in a litter $(35.2,5)$; Appian provides a detailed narrative of a violent pre-trial contio (2.20.2, rather different from Asconius 33C); Dio provides an anecdote about Milo's reception of the published speech-text (40.54.3-4) and comments on Cicero's role in the trial of Plancus (40.55.4). These unique elements confirm that our four texts do not descend from one another in a straight line. It is not my aim here to establish a 'genealogy' of sources, and studies of Cicero's ancient reception should bear in mind the wealth of material on which even the earliest of our extant sources could have drawn. However, it is clear that the 'meaning and value' of Cicero and his actions were 'contested' from his own lifetime onwards. ${ }^{8}$ In addition to written works whose existence we know for certain (such as Asinius Pollio's history, generally understood as the root of the anti-Ciceronian tradition), ${ }^{9}$ the declamationes on Cicero's death recorded by Seneca (Suas. 6-7, cf. Contr. 7.2) provide a salutary reminder that sources could have been oral as well as written. ${ }^{10}$ In what follows it will be assumed that all our authors had access to a number of versions of what happened, and that their decisions about which elements and variations to include are significant in terms of the purpose of each work.

\section{PLUTARCH}

Plutarch's omissions in this section of his biography are substantial. Between Cicero's recall from exile in $57 \mathrm{BC}$ and his proconsulship in $51 \mathrm{BC}$, he mentions only the removal of Clodius' tribunician records,

${ }^{8}$ I here paraphrase Roller 1997: 116 on the tradition concerning Cicero's death. For competing views on the meaning of Milo's trial and the Pro Milone, see Fotheringham 2006; for the Pro Milone itself as contesting the meaning of Clodius' death, see Steel 2005: 119.

9 For Pollio's importance as a source for this period, see e.g. Homeyer 1977 [1964], Pelling 2002a: 12-24; for a recent exploration of his historiographical persona, see Morgan 2000; for his anti-Ciceronian attitude see Sen. Contr. 6.14 with Roller 1997: 115-16.

${ }^{10}$ In addition to Roller 1997, see Wright 2001 on the problematic evidence of these declamations. 
the trial of Milo, and the election to the augurate-in that unchronological sequence. The lack of careful political contextualization in the episode of the trial itself confirms that the event is not included because of its broader political significance, but nonetheless it still coheres well with its immediate context. It remains to ask why Plutarch's approach to the late 50 s is so patchy, ${ }^{11}$ and why he includes those few episodes he does include.

One possible explanation for this patchiness of the narrative of the 50 s is ignorance. It has been argued from the nature of Plutarch's other late-Republican Lives (written later) that he found a synoptic narrative source while composing the Cicero, probably Asinius Pollio or one of his followers. This supplied him both with further information and left him with less need to rely on primary sources such as Cicero's speeches and letters. ${ }^{12}$ It is nevertheless implausible to attribute every omission from the Cicero to ignorance. Plutarch must have known of more than three events from Cicero's life between 57 and 51 BC. He cites Tiro's biography of Cicero (Cicero 41.4, 49.4), and the attacks on Cicero in Antonius' replies to the Philippics (Cicero 41.6). The former is less likely to have ignored the 50s BC (however humiliating some of the decade's events had been for Cicero) than to have presented some kind of apologia; and the latter would probably have referred to some incidents which revealed Cicero's powerlessness and could be read as evidence for his supposedly 'turncoat' nature (for example, the support of the dynasts in the De Provinciis Consularibus, and Cicero's embarrassing defence of Gabinius).

Even though Plutarch is writing a biography of Cicero, it is also noteworthy that the orator's activities are not the only ones omitted from the narrative. In strong contrast to the accounts of Appian and Dio, Pompeius and Caesar are completely absent from the post-exile narrative, except for Pompeius' appearance at Cicero 35.1, where only the merest outline of his role in events is given. Plutarch constructs a narrative in which the civil war bursts on the reader at Cicero 37.1 without preparation or explanation; indeed, the last time Pompeius and Caesar were mentioned together, they were operating together (Cic. 31.3). It seems much more likely that Plutarch is here assuming general knowledge of the period in his reader, rather than that he

11 For criticism of the 'patchy' narrative here, see Pelling 2002a: 2-3, 27-8 (contra Steidle 1990: 168-9); Moles 1988: 33, 47.

12 Pelling 2002a: 1-3, 12-13, 16-18. 
himself is ignorant of the increasing tension at Rome. Pompeius' activities in particular are also alluded to, instead of being fully explained elsewhere in the biography. ${ }^{13}$

Rather than attributing all omissions to ignorance, let us consider the structure and overall thrust of the biography. The Cicero falls into two halves: chapters 1-23 offer a largely positive narrative of the period up to the consulship (although not without foreshadowing of troubles to come) ${ }^{14}$ chapters $28-49$ lay out a more negative narrative of the period following it. Between the two is placed, in partial explanation of the change in Cicero's fortunes, an extensive analysis of those habits of speaking which alienated his contemporaries (24-7): his self-praise, his criticism of others, and his frequently obnoxious wit (which is first mentioned at 5.6). The careful political contextualizations for Cicero's early career and for Catiline's conspiracy occur in the first half of the biography. ${ }^{15}$ The first comes very early, where such scene-setting seems natural (3.3); the second is more clearly a step back from the ongoing narrative to consider the political context. Its ultimate purpose is to explain the surprising support Cicero received in his consular election (10.2-5). The third passage (12.2) is no longer necessary to explain this support, but builds on the remarks made at 10.2 in order to provide information about the struggles which Cicero faced during the consulship itself. Plutarch was aware of the difficulties faced by Cicero as a 'new man' in the elitist world of late Republican politics. ${ }^{16}$ It may be that Plutarch found historical context necessary to explain the orator's remarkable rise, but his own character flaws adequate to explain his fall. This would explain why the most detailed political contextualization in the biography occurs at 10.2-5; nothing else requires so much explanation as Cicero's rise. ${ }^{17}$

What unites the events narrated at Cicero $34-5$ is the involvement of Clodius. The chronological displacement of the election of the

\footnotetext{
13 Compare the references at Cic. 8.7, 9.4, 10.2. Steidle 1990: 165-6 gives a list of omissions from this biography where an audience's knowledge seems to be assumed.

14 There is explicit prolepsis at Cic. 6.5, less explicit at 5.6; towards the end of the consular narrative, things start to look a little less positive, with Cicero unsure what to do at 19.6-21.3, and under attack at 23.1-4. The first explicitly negative comment comes at 24.1.

15 See Pelling 2002a: 55-6. $\quad 16$ Pelling 2002a: 208; Moles 1988: 21.

17 Cf. Pelling 2002a: 128 on the disappearance of the demos from the second half of the Nicias.
} 
augurate $(53 \mathrm{BC})$ to Cicero 36.1 can in part be explained by the fact that this information is not related to Clodius. Pace Moles (1988: 9, 182), I find it difficult to see chapters $34-5$ as separate from the preceding exile-narrative (Cicero 28-33), although Moles may be right that the two episodes illustrate 'contrasting political weaknesses' as well as rounding off a Clodius-narrative. ${ }^{18}$ Plutarch selects one example of dispute to represent the ongoing conflict between Cicero and Clodius about the meaning of his exile and recall, and recounts the last act: the death of Clodius and its coda (for death is not ever, quite, the end), namely Milo's trial. The Clodius-narrative is part of a sequence: the conflicts between Cicero and his adversaries (Catiline, Lentulus, Clodius and Antonius) are the subject of fairly sustained narrative sections (Cicero 10-16 with 22.8, 17-22, 28-35, 42-9). In contrast, the accounts of Cicero's life before the consulship (Cicero 3.1-9.7), and between Clodius' death and Caesar's assassination (Cicero 36-42.1), are more diffuse in focus, characterized by a backand-forth movement between his political and intellectual lives. Cicero's opposition to Sulla comes in the first of these sections, and his interactions with Caesar are key in the second (although opposition to Caesar goes back to 20.5), but the different narrative approach to these prominent figures suggests that Plutarch focused on those opponents whose actions were directed more at Cicero himself, whether as consul (Catiline and Lentulus) or as personal enemy (Clodius and Antonius). This is an understandable choice in a biographer, and reflects his general tendency in this biography not to evoke the political background except where it is necessary to explain something.

One reason for Plutarch to include the trial of Milo is because it provides a convenient closing-point for the Clodius-narrative, the first coherent section of the second half of the Life. Yet the episode is also connected to its context thematically. Most importantly, the explanation of Cicero's below-par performance at the trial (Cicero's fear of the soldiers) lends itself ideally to a central theme which runs through the Demosthenes-Cicero pair, namely the varying levels of

18 Texts have multiple structures (as Moles acknowledges) and multiple functions. His references to ring-composition in Cicero 28-33 seem to mean that there are a number of 'rings' within this passage; he does not note specific verbal echoes at its beginning and end. 
courage and timidity shown by these two orators. ${ }^{19}$ Plutarch could therefore have known the version in which Cicero's poor performance was due to the heckling of the Clodiani, but he would have had a compelling artistic reason to prefer fear of the soldiers as the cause. The anecdote about the litter and the digression on Cicero's general nervousness when speaking (Cicero 35.3-4) show Plutarch making the most of the theme. Comments in Cicero's speeches have been cited to support the historicity of this claim. Yet we should be wary of reading so literally what may originally have been attempts to win the iudices' sympathy, ${ }^{20}$ even if precisely such a literal reading could have been seized on by writers in the anti-Ciceronian tradition. ${ }^{21}$

Other elements of the episode are also made to echo features of the Cicero as a whole. So, Milo's refusal to wear mourning reverses an aspect of the trial of Licinius Macer (Cicero 9.2). Macer, on trial de repetundis under Cicero's praetorship, got rid of his mourning apparel too soon, on the false assumption that he would be acquitted. Now, in a kind of reversal, Cicero's client Milo is condemned (according to Plutarch) because he refused to adopt clothes of mourning in the first place. ${ }^{22}$ Perhaps more significantly, this is the third occasion in the biography where Plutarch emphasizes Cicero's not speaking. At Cicero 7.4 he forgoes his prosecution speech at the trial of Verres, and wins the case. Plutarch notes the irony explicitly. At Cicero 23.2 the tribunes attempt to prevent Cicero speaking at the end of his consulship. Although he forgoes a long speech, he still manages to turn the tables on them by adapting the wording of his year-end oath. This third occasion is different, and marks the downturn in Cicero's fortunes: instead of choosing not to speak, he tries to speak and

19 The theme is introduced at Dem. 3.3. For its use in the Cicero, see Moles 1988: 152 on Cic. 3.5. Unfortunately, there is not space here to explore the relationship between the Cicero and the Demosthenes in more detail, but see Mossman 1999, Lintott 2013.

20 Moles 1988: 183 on Cic. 35.3 cites Pro Cluentio 51, Pro Caecina 41, Pro Rege Deiotaro 1.

${ }^{21}$ See Fotheringham 2006: 73-4 (for the Pro Murena anecdote and the possibility of misreading) and 67, n. 2 (for the danger of taking the exordium a timore too literally). Antonius' responses to the Philippics are possibly the primary source for this trope, which also surfaces in Fufius Calenus' attack at Dio Roman History 46.7.2.

${ }^{22}$ Two non-judicial changes of clothing also occur. At Cic. 19.3, Lentulus changes clothing when his guilt is demonstrated: mourning gear is not specified, but likely. At Cic. 30.6-31.1 Cicero changes clothing when threatened with exile, and his supporters do likewise (or wish to). 
fails. Asconius' account suggests that some kind of speech was delivered (42C), but Plutarch has an artistic reason for preferring the more extreme version.

The closing comment of the episode (Cicero 35.5 ad fin.) states that

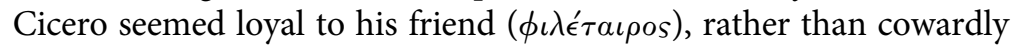
( $\left.\delta \epsilon \iota \lambda o_{\text {ós}}\right)$. Here Plutarch's version coheres with Asconius' reading. ${ }^{23}$ This has been seen as 'at odds with' Plutarch's earlier emphasis on Cicero's fear of the soldiers, ${ }^{24}$ but Cicero's general timidity could even be understood as making his very attempt to defend Milo an act of bravery in itself, even if it did not get very far. There may be more sympathy for Cicero's nervousness in Plutarch than, for example, in Dio, who is notoriously negative about the orator. After mentioning

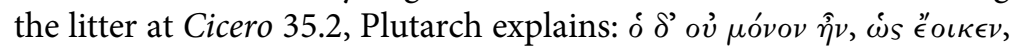

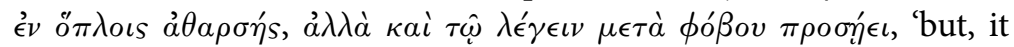
seems, Cicero was not only lacking in boldness when surrounded by weapons, but also approached speaking with fear'. This claim goes beyond what is necessary to explain Cicero's fear on this occasion, since he is surrounded by weapons ( ${ }^{\prime \prime} \pi \lambda \alpha, C i c$. 35.5). The choice of Murena's trial to illustrate the claim (Cic. 35.4) is surprising, and it is generally seen as implausible and incompatible even with Plutarch's own other reference to that trial (Demosthenes-Cicero Syncrisis 1 [50].4). ${ }^{25}$ Perhaps the success of Cicero's defence on that occasion was the very reason it was selected: if Plutarch can convince the reader that Cicero was nervous at the time of the Pro Murena, his nerves at the trial of Milo do not seem so surprising. Both the generalities and the particulars of the digression therefore work to normalize Cicero's fear on this occasion. At the same time, since the defence of Murena was successful, this nervousness is not necessarily associated with failure, and it takes the presence of weapons in the forum to confound Cicero so utterly that he cannot speak.

If the account of Milo's trial can be read as a mixture of positive and negative elements, this is entirely appropriate at this juncture in the biography. The shift from positive to negative in the second half

23 Asconius 38C: tanta tamen constantia ac fides fuit Ciceronis ut . . non armis... deterreri potuerit a defensione eius [Milonis]. Quintilian, generally positive about Cicero, mentions interruptions from the crowd (4.3.17) and attributes courage to him (2.20.8). Yet the Bobbio scholiast sees evidence of fear in the text (Fotheringham 2006: 76).

${ }^{24}$ Moles 1988: $184 . \quad 25$ Moles 1988: 183; Lintott 2013: 186. 
is not abrupt but gradual, ${ }^{26}$ and the Clodius-narrative is particularly mixed. The exile is obviously a setback, but it is followed by triumphant recall (note especially Cic. 33.7). Cicero's behaviour is sometimes cast in a negative light (Cic. 29.2-4, 30.3-4, 32.5-7), but so is that of those who oppose or abandon him (especially Pompeius, Cic. 31.3), and the emphasis on the degree of support he receives suggests that he is in the right (Cic. 31.1). The positive judgement (calling Cicero

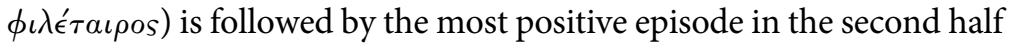
of the biography, namely his governorship of Cilicia (Cic. 36). Thereafter the negative moments accumulate. ${ }^{27}$ The governorship is a lull before the storm (the next lull, during Caesar's dictatorship, has an entirely different flavour; Cic. 40.2-3), and the judgement that Cicero was not $\delta \epsilon \iota$ 'ós leads into it.

In this as in many other respects, the episode is thoroughly integrated into its literary context. It is also not without historical insight: Cicero's mindset in 52 would have been a mixture of delight-over Clodius' death and his judicial successes later in the year-and disappointment-over his failure to achieve Milo's acquittal. If the overall impression has historical value, the details are not necessarily to be relied upon, especially when they fit so neatly into overarching themes. We should, however, give Plutarch credit for his selection of telling details and variants from the huge mass of conflicting material likely to have been available to him.

\section{CASSIUS DIO}

The amount of space devoted to $52 \mathrm{BC}$ in book 40 strongly suggests that Dio felt the events of that year to be important, and the sole consulship of Pompeius is likely to be the reason. At 40.50 .5 it is explicitly stated that by this unprecedented honour the senate finally succeeded in detaching the great man from Caesar and from the people. In Dio's account, this is almost the last event of any

\footnotetext{
26 See n.14 above.

27 There are positive moments after chapter 36, but they are fleeting, double-edged, non-political, or posthumous: intellectual achievements (Cic. 39.7-40.3); amnestyspeech (Cic. 42.3); welcomed back to Italy (Cic. 43.5); power in the city (Cic. 45.4); praise by Augustus (Cic. 49.5).
} 
significance in the run-up to the civil war: he gives very little information about M. Marcellus' opposition to Caesar in 51 BC (40.59.1, 4), moving swiftly on to Caesar's wooing of Curio (40.60.2-61.1). The reason for the detailed account of the skirmish in which Clodius died, and of the subsequent increased violence in the city (40.48.2-49.5), is that these events served as a catalyst for the sole consulship. Still more details about the events of that year are also provided. ${ }^{28}$ It is not likely that all these details are due simply to the fact that Dio's sources gave more information about $52 \mathrm{BC}$ than $53 \mathrm{BC}$ or $51 \mathrm{BC}$. At the same time, the comparison with Appian demonstrates that the events of 52 $\mathrm{BC}$ could be narrated with a different emphasis; the material relating to Cicero at Dio 40.54.3-4 and 55.4 could easily have been omitted without leaving any obvious gaps in the narrative. Its pointed inclusion can therefore serve as an interesting entry into the question of Dio's attitude to Cicero overall.

Dio's earlier narratives of Milo's efforts on behalf of Cicero's recall (39.6-8) and his ongoing role in the conflict between Cicero and Clodius (39.18-21) suggest that some care has been taken to prepare for the events of $52 \mathrm{BC}$. The narrative itself, however, is repetitive, digressive, and even confusing. At 40.49.5-50.1 the same resolution of the senate is referred to twice, and what looks like additional information in the second sentence may also belong to that resolution. The three consular candidates for 52 BC, whose identity opens Asconius' more straightforward narrative (30C), are only gradually revealed by Dio: Milo (40.48.2), Scipio (40.51.3), and Hypsaeus (40.53.1). ${ }^{29}$ The fact that Milo was convicted is mentioned no less than three times $(40.53 .2,54.1,55.1)$. It is not entirely clear whether Dio believes that the killing of citizens by Pompeius' soldiers took place at Milo's trial or not: his initial reference to the soldiers is in the context of explaining Milo's inability to use force, and here he uses the singular

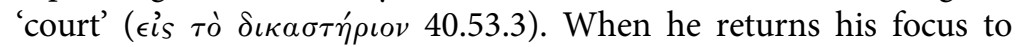
Milo's conviction, however, he makes a general statement about the

\footnotetext{
28 Note the provision of such background information as the reason for the senate's assigning Faustus Sulla to rebuild the curia (40.50.2) and the family background of Scipio Nasica (40.51.3). The former creates a link to the last Roman dictatorship; the latter focuses on Pompeius' new father-in-law in the wake of Julia's death (40.44.3; cf. 39.64.1).

29 Unlike Appian (BC 2.20; cf. Asc. 31C), Dio is not interested in Pompeius' interaction with Milo as consular candidate before the skirmish.
} 
consequent peaceful conduct of the 'courts' ( Given the care Dio has taken to prepare for the role played by Milo in this year, the potentially confusing elements of the actual narrative can be read as a deliberate choice, reflecting the frenetic and confusing activity of this year. ${ }^{31}$

The overall structure of book 40 backs up the claim that Dio uses the structure of his narrative to reflect content. Our understanding of the structure of the work as a whole is compromised by the amount that has been lost, but books 36-39 establish a pattern which is broken in book 40. The beginning of 36 is lost, but 37-39 all open with a new year; the start of book 40, in contrast, continues the account of $54 \mathrm{BC}$ in a new geographical theatre. The organization of this book as whole is geographical rather than chronological. Dio has twice extended the narrative in one geographical theatre to cover two years, before looping back to cover the same years elsewhere, ${ }^{32}$ and there are several carefully-marked prolepses. ${ }^{33}$ Nevertheless, the organization of material has been primarily annalistic. ${ }^{34}$ In book 40 as a whole the annalistic pattern is abandoned in favour of a

30 The claim that the appearance of the court was the same at Plancus' trial (40.55.4) confirms that Dio believed the soldiers were present at other trials besides Milo's. The only other writer who gives the impression that the presence of soldiers was a general feature of the trials of the period is Appian (BC 2.24). He also supports Dio's claim that the soldiers killed some citizens, identifying the occasion as the trial of Scaurus. Here he is muddled; the trial he is referring to is the one that took place in 54 BC (Bucher 1995), not, as I mistakenly state at 2006: 74, later in $52 \mathrm{BC}$. He is also wrong about the date of Gabinius' trial; he seems to be cramming into the judicial history of $52 \mathrm{BC}$ various prosecutions which actually took place at a different date and were notorious for some other reason, but it is unlikely that the details about the presence of the soldiers and the killing of protestors are also imported from another year.

31 In the wake of work such as Fechner 1986 and Gowing 1992, not to mention a host of work on Dio's imperial narratives, I hope that it is no longer necessary to argue against the interpretation that Dio is simply being incompetent here.

32 65-64 BC: 37.1-7 in Asia (followed by a lacuna); then 37.8-10 in Rome. 56-55 BC: $39.15-39$ in Rome; then 39.40-60 in Gaul, Spain, and Egypt.

${ }^{33}$ The most substantial is that of the aftermath of Pompeius' Eastern victory (37.20-3).

34 The criticisms of Lintott (1997) are too strict. Dio's errors do not mean that he was not aiming at conveying an annalist structure. The accounts of individual years do not conform to the supposedly standard sequence: naming of the consuls-events at Rome-events in the provinces-return to Rome (round-up of prodigies, etc.). The standardization of this sequence, however, has been called into question even for Livy, the annalistic historian par excellence (Rich 2011). On Dio's free use of the form, see Swan 1987 and 2004: 17-21; Pelling 1997b: 117. 
geographical organization: Gaul (54 BC), 40.1-11; the East (54-51 BC), 40.12-30; Gaul (53-50 BC), 40.31-44; Rome (53-50 BC), 40.45-66. With the civil war beginning in the new decad, ${ }^{35}$ the breakdown of the consular year as an annalistic structural element in book 40 can be seen as anticipating the breakdown of republican government, which will be manifest in the Civil War, but is already present in the failure to hold consular elections for $53 \mathrm{BC}$ and $52 \mathrm{BC}$ at the proper time $(40.45-48) .^{36}$

In the account of $52 \mathrm{BC}$ itself, the focus moves constantly away from and back to Pompeius. His longest absence from the narrative is in 40.46.2-49.4, where the exciting narrative of the skirmish and subsequent violence takes over. In the account of the judicial aftermath, the list of people prosecuted or threatened with prosecution (Scipio Nasica, Hypsaeus, Milo, Rufus, and Plancus) is repeatedly interrupted by explanatory comments about Pompeius' legislative or other actions: $\gamma \dot{\alpha} \rho$ at 40.52.1, 53.5, 55.2; resumptive ov̉v at 40.53.1, 54.1, $\mu \epsilon^{\prime} \nu \tau o \iota$ at 40.55.3. This structure allows Dio to keep Pompeius in the picture throughout his account of the various trials.

Another $\gamma \grave{\alpha} \rho-o \hat{v} v$ sequence frames the digression on Cicero's performance at Milo's trial and the subsequent publication (40.54.2-55.1). It is easy to read Dio as going out of his way to be negative about Cicero here. His introduction implies acknowledgement of his oratorical skill: the reader is expected to be surprised at Milo's conviction

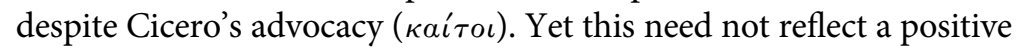
view of the character and behaviour of the skilled man, and the skill may have been difficult to deny. ${ }^{37}$ Fear of the soldiers might have been understandable, and Dio is capable of using this event to underline the disintegration of due legal process even after Pompeius' attempt to make the system work again. However, Dio goes on to imagine Milo as coming to an extremely negative judgement: Cicero could do nothing useful at the trial, and now wastes his time on pointless speeches which cannot help. ${ }^{38}$ Dio overlooks the possibility

\footnotetext{
35 For the significance of decads in the structure of the whole work, suggested by this and by the establishment of the Augustan principate in book 51, see Millar 1964: $38-9$.

${ }^{36}$ For similar play with the annalistic structure see Rich 2011: 13-15 (Livy), Feeney 2007: 190-6 (Tacitus).

37 It is also possible that the кaíroı-comment is ironic, or included to increase the sense of Cicero's failure on this occasion.

38 I discuss Dio's interpretation of Milo's joke at 2006: 75, with n. 2.
} 
that the publication of the Pro Milone was a blow in the fight for Milo's recall. ${ }^{39}$ In terms of the wider narrative of $52 \mathrm{BC}$ as a whole, this part of the anecdote serves little obvious function.

Cicero is again unnecessary in the account of Plancus' trial: the story about Pompeius' attempt to break his own recent law is more telling in terms of the political situation than the comment that Cicero's prosecution of Plancus was 'no better' than his defence of Milo (40.55.4) - whatever that means. On this occasion Cicero was successful, and in a letter (Fam. 7.2) he declares himself delighted. Perhaps Dio is referring only to the longer-term results of this action in terms of Cicero's relationship with Pompeius, which he goes on to explain as he explained Milo's joke. These two trials are not the only point in Dio where Cicero plays an unnecessarily enlarged role, with one of the most striking examples being the conversation with Philiscus (38.18-29). Philiscus is critical of Cicero's attitude during his exile (as is Plutarch, Cic. 32.6-7), but his upbraiding of the orator includes encouragement to remember his great achievements, and so involves praise. It could be debated whether praise or criticism is the dominant element, but the praise is there, and it need not have been. Dio's handling of the Catilinarian conspiracy is also generally positive. This has been explained away as due to the use of Cicero's own memoir on his consulship as the source for the narrative, ${ }^{40}$ but it is not plausible that Dio would simply believe everything Cicero says, or that he would have had no exposure to alternative, more negative accounts.

Although it would be difficult to argue for a positive view of Cicero in Dio's account of Milo's trial, one element which this account has in common with the Philiscus debate is that Cicero is not allowed to speak (much), ${ }^{41}$ and this is true of books $36-40$ as a whole. We cannot be certain how Dio handled the trials of Roscius and Verres (if at all), but if his treatment of the Catilinarian conspiracy is anything to go by, he could have told these stories too without giving Cicero a speech. There are a number of possible reasons for a historiographer not to try and imitate Cicero, but when after Caesar's death he is finally allowed to speak, twice (and also is granted a response in the debate with Calenus), it is possible to reinterpret the earlier silence as suspenseful. The speeches Dio allows Cicero therefore acquire still

\footnotetext{
39 See Melchior 2008. $\quad 40$ Pelling 2002a: 46, with 60, n. 9.
}

41 See Rich 1989: 98 on the oddity of Dio's private debates. 
more significance, since the reader has been made to wait so long for them. A recent Oxford D.Phil. proposes an ironic reading: for example, in the speech about amnesty, Cicero's proposal is a good one, but doomed to failure due to the competitive ambitions endemic to the period-ambition which Dio's account has emphasized throughout, showing Cicero to be as tarnished with it as any of his contemporaries. ${ }^{42}$ This reading has the merit of taking Dio's Cicero seriously as an emblem of late Republican politics, rather than simply as the butt of an incompetent historian's dislike.

This discussion of Dio's Cicero has led me a long way from the account of Milo's trial, but my avowed aim was to consider that account in the context of Dio's work more broadly. In a work of this length, a single incident cannot carry as much weight as in a shorter work like Plutarch's Life. Nevertheless it is possible to see in Dio's account, including his emphasis on Cicero's failure to speak at Milo's trial (and on the negative results of what was on the surface a success at Plancus' trial), reflections of his concern with the breakdown of Republican due process under the pressures of the ambitions shown not only by the dynasts but also by their less powerful contemporaries. Dio's Cicero is presented as a political failure in a variety of ways, but the amount of space devoted to that failure suggests that Dio found it an interesting one; this may also have been true of other contributors to the anti-Ciceronian tradition.

\section{CONCLUSION}

Plutarch and Dio are generally considered less trustworthy witnesses than Asconius, and recent articles (e.g. Dyck 2002) have confirmed the consensus that their explanation of Cicero's below-par performance at Milo's trial is not to be relied on. This further exploration of the contexts of their accounts confirms this unreliability, since it has shown that both writers had literary motivations for selecting this version of events as fitting certain wider themes. Their picture of Cicero stumbling over his words through fear has nevertheless 
gripped many an imagination; ${ }^{43}$ this may say something about ongoing anti-Ciceronian feeling down to the present day. Yet it is also testimony to the story-telling powers of Plutarch and Dio themselves. If I have impugned their veracity, I hope at the same time to have indicated that they are worth taking seriously as evidence not so much for what happened in Cicero's lifetime, but for the variety of interesting things that could be thought about him after his death.

43 The story makes its way into biographies by Stockton 1971, Rawson 1975 and Shackleton Bailey 1971, among many others. 
